\title{
EFFECT OF MALTODEXTRIN ON THE FREEZING POINT AND THERMAL CONDUCTIVITY OF UVAIA PULP (Eugenia piriformis Cambess)
}

\author{
Efeito da maltodextrina no ponto de congelamento e condutividade \\ térmica de polpa de uvaia (Eugenia piriformis Cambess)
}

\author{
Harvey Alexander Villa-Vélez ${ }^{1}$, Javier Telis-Romero ${ }^{1}$, Diana Maria Cano Higuita ${ }^{1}$, Vânia Regina Nicolletti Telis ${ }^{2}$
}

\begin{abstract}
The freezing point depression (FPD) of uvaia pulp with and without additives - 10, 16, 22 and $28 \%$ of maltodextrin (MD), was measured using a simple apparatus consisting of two major sections: a freezing vessel and a data acquisition system. The thermal conductivity of the pulps was also investigated as a function of the frozen water fraction and temperature using a coaxial dualcylinder apparatus. Above the initial freezing point, thermal conductivity fitted the polynomial equations well. Below the freezing point, thermal conductivity was strongly affected by both the frozen water fraction and the temperature. Simple equations in terms of the frozen water fraction and temperature could be fitted to the experimental data for freezing point depression and thermal conductivity.
\end{abstract}

Indexing terms: Freezing point depression, uvaia pulp, thermal conductivity.

\section{RESUMO}

O ponto de início de congelamento (FPD) da polpa de uvaia com e sem aditivos - 10, 16, 22 e $28 \%$ de maltodextrina (MD), foi medido por um aparelho simples, que consiste de duas seções principais: um vaso de congelamento e um sistema de aquisição de dados. A condutividade térmica foi calculada em função da fração de água congelada e da temperatura, usando um aparelho cilíndrico coaxial duplo. Foram empregadas equações polinomiais para descrever o comportamento do ponto inicial de congelamento e da condutividade térmica. Abaixo do ponto de congelamento, a condutividade térmica foi fortemente afetada pela fração de água congelada e pela temperatura. Equações simples em termos da fração de água congelada e da temperatura podem ser ajustadas aos dados experimentais no cálculo do início do ponto de congelamento e da condutividade térmica.

Termos para indexação: Ponto de início do congelamento, polpa de uvaia, condutividade térmica.

\section{(Received in february 1, 2012 and approved in february 29, 2012)}

\section{INTRODUCTION}

Brazil is the largest worldwide exporter of concentrated juices; principally of tropical and Amazonian fruits. Some tropical countries such as Thailand, India, the Philippines and China, have large crops grown for exportation (FAOSTAT, 2009) but part of the production does not meet minimal standards for exportation and is lost after harvesting. A similar case occurs with the Amazonian fruits, where production and industrial application are small (SCALON et al., 2004). The uvaia (Eugenia pyriformis Cambess) also known as uvalha, ubaia and avair-pear is a native of the Brazilian Atlantic forest. The fruit is a yellow, velvety, pyriform and edible berry chemically composed of $90.7 \%$ of water, $7.5 \%$ of soluble solids, with a total soluble solids (TSS)/total titratable

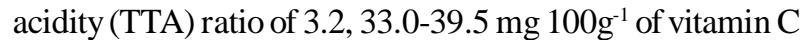
and $1.5 \%$ of acidity (RUFINO et al., 2009; DONADIO, 1997). The fruits have a sweet, acidic mesocarp and are used to produce juice, vinegar, wine and liqueurs (GUEDES et al., 2009). Like most wild Brazilian fruit species, it is not marketed extensively, and basic information about its propagation, cultivation and industrialization is not available (CHOUDHARY; MEHTA, 2010).

Drying the fruit pulp converts it to a stable, easilyhandled form that reconstitutes rapidly to a good quality product closely resembling the original. Dried pulp products are used mainly as convenience foods and have a long storage life at ordinary temperatures. Nevertheless, the drying of fruit pulps and other products with high sugar contents presents technical difficulties because of their hygroscopicity and thermoplasticity at high temperatures and humidities. The high hygroscopicity and thermoplastic nature of fruit juice powders give rise to problems such as: adhesion to the dryer walls; difficult handling; and caking (AHMED, 2011). Therefore, the use of additives such as maltodextrin and arabic gum (as well as other substances

${ }^{1}$ Universidade Estadual Paulista/UNESP - Departamento de Engenharia e Tecnologia de Alimentos - São José do Rio Preto - SP - Brasil

2Universidade Estadual Paulista/UNESP - Departamento de Engenharia e Tecnologia de Alimentos - 15054-000 - São José do Rio Preto - SP - Brasil vanianic@ibilce.unesp.br

Ciênc. agrotec., Lavras, v. 36, n. 1, p. 78-85, jan./fev., 2012 
such as pectins, calcium silicate and carboxy-methyl cellulose) to facilitate drying and improve the transport and storage properties of the powder, is generally mandatory (ROUSTAPOUR et al., 2006; ADHIKARI et al., 2004).

Maltodextrins consist of $\beta$-D-glucose units linked mainly by glycosidic bonds $(1 \rightarrow 4)$ and are usually classified according to their dextrose equivalency (DE). The DE of a maltodextrin determines its reducing capacity and is inversely related to its average molecular weight (BEMILLER, 1996). This material is mainly used as an encapsulant of products that are difficult to dry - such as fruit juices, flavorings and sweeteners (REINECCIUS, 1991) - and to reduce stickiness and agglomeration problems during storage, thereby improving product stability (JAYA; DAS, 2004). In addition, they provide good retention of volatile substances and confer effective protection against oxidation (RIGHETTO; NETTO, 2005).

Knowledge of the thermal properties of frozen uvaia pulps is essential to calculate the temperature distribution during freezing and frozen storage, and to estimate the freezing time. Food engineers are interested in predicting freezing times in order to estimate the refrigeration requirements for freezing systems, and to design the necessary equipment for effective processing. Energy efficiency, reliability, safety, and quality of the final product must also be considered (DELGADO; SUN, 2001).

The freezing point temperature relative to $0^{\circ} \mathrm{C}$, also called the "freezing point depression" (FPD), which increases with increasing solute concentration, is an important thermophysical property in freezing processes. It is known that the freeze-drying process involves freezing of the fresh product, heating of the frozen foods at low temperature to induce sublimation, condensation of the water vapor and the consumption of mechanical energy to maintain the vacuum. The main disadvantage of this technique is the high capital and operating costs, limiting its use in the food industry and restricting freeze-drying to the dehydration of high-added value products such as instant coffee or baby foods. However, the freeze-drying of fruits and vegetables has recently been proposed for use as high quality ingredients in ready-to-prepare soups, snacks and delicacies (DI MATTEO et al., 2003). Considering this, knowledge of the thermophysical properties related to the freezing of fruit pulps is important in the wider context of freeze-drying research (CHEN et al., 1996; LERICI et al., 1983).

The aim of this work was to determine the freezing point depression and thermal conductivity of uvaia pulps with added maltodextrin, as affected by the frozen water fraction and temperatures from -25 to $75^{\circ} \mathrm{C}$.

\section{MATERIAL AND METHODS}

Raw materials: samples of uvaia (Eugenia piriformis Cambess) with soluble solid contents of 6.2 to $6.9^{\circ}$ Brix; moisture contents of 87 to $89 \%$ (wet basis) and total sugars of $8.4 \mathrm{~g} / 100 \mathrm{~g}$, picked in the Ceara region, were obtained from a local market in São José do Rio Preto (SP, Brazil) and stored at $7^{\circ} \mathrm{C}$ prior to use. A batch of uvaia pulp was prepared in a pilot plant finisher and sieved through a $1.6 \mathrm{~mm}-\mathrm{mesh}$.

Sample Preparation: an aqueous solution with 50\% solids (mass basis) was prepared by dispersing the commercial maltodextrin MOR-REX ${ }^{\circledR} 1920$ (Corn Products Brazil) in distilled water at $40^{\circ} \mathrm{C}$, using a mechanical stirrer. This solution was added to the uvaia pulp, and the mass ratio between the maltodextrin solution and pulp was calculated to provide 10, 16, 22 and $28 \%$ maltodextrin (MD) content on a dry weight basis (i.e. 10, 16, 22 and $28 \mathrm{~g}$ of maltodextrin $/ 100 \mathrm{~g}$ total solids). According to the technical specifications provided by the manufacturer, maltodextrin MOR-REX ${ }^{\circledR} 1920$ presents $17.0 \leq \mathrm{DE} \geq 19.9$.

After processing, the pulps were quickly platefrozen and stored at $-20^{\circ} \mathrm{C}$ until used in the experiment.

Determination of the freezing point depression: the FPD was calculated using equipment built on a laboratory scale, as described in Figure 1. The equipment consisted of an acrylic sample holder cylinder (inner diameter $2.7 \mathrm{~cm}$, height $12.5 \mathrm{~cm}$ and a wall thickness of 1 $\mathrm{mm}$ ), connected to a thermostatic cooling bath (Marconi, Brazil), using an ethylene glycol-water mixture (50:50) as the coolant, allowing it to reach cooling temperatures of $50 \mathrm{C}$. The temperature of the equipment was maintained at $-30^{\circ} \mathrm{C}$ for all the experiments. For the experiments, each sample of uvaia pulp was placed inside the sample holder cylinder, which was cooled by the thermostatic bath. The

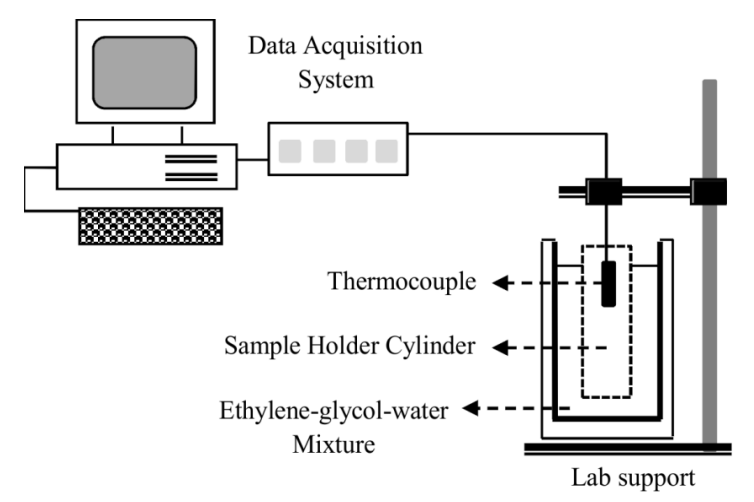

Figure 1 - Schematic diagram of the apparatus used to measure the freezing point depression. 
temperature of the sample contained in the cylinder was measured using a thermocouple (calibrated with ethyleneglycol), fixed in a lab support. The thermocouple was placed at a distance of $9 \mathrm{~cm}$ inside the cylinder (from the surface to the base), and transmitted data at $1 \mathrm{~min}$ time intervals by means of a data acquisition system (Model NI 9213, National Instruments, USA) (TELIS et al., 2007; CHEN et al., 1996).

Before the experiment, the apparatus used to measure the freezing point depression was calibrated using ethylene glycol, which has a well-known FPD (TELISROMERO et al., 1998). Eleven replicate experiments were carried out, obtaining a standard deviation of $(\mathrm{SD}=0.737)$ and standard error of $(\mathrm{SE}=0.145)$.

Determination of the thermal conductivity: the system used to measure thermal conductivity was a coaxial dual-cylinder apparatus, as per the schematic shown in Figure 2. This method was used by Telis-Romero et al. $(1998,2000)$ to measure the thermal conductivity of orange juice and coffee extract above the freezing point. The heat source was a uniformly distributed electric resistance heater inserted along the axis of the inner cylinder (1055 $\mathrm{mm}$ long and $127 \mathrm{~mm}$ in diameter) to provide a radial heat flux. The samples were loaded into the annular space between the inner and outer cylinders (inner diameter of $42 \mathrm{~mm}$ and length of $220 \mathrm{~mm}$ ), with both ends fitted with nylon stoppers to prevent axial heat transfer. Before being loaded, the samples were degassed under vacuum for $20 \mathrm{~min}$ to remove air bubbles. Only $95 \%$ of the available volume was filled with sample in order to allow for expansion during freezing. The apparatus was then immersed in a thermostatic bath (model MA-184, Marconi, São Paulo, Brazil) containing ethyl alcohol. The

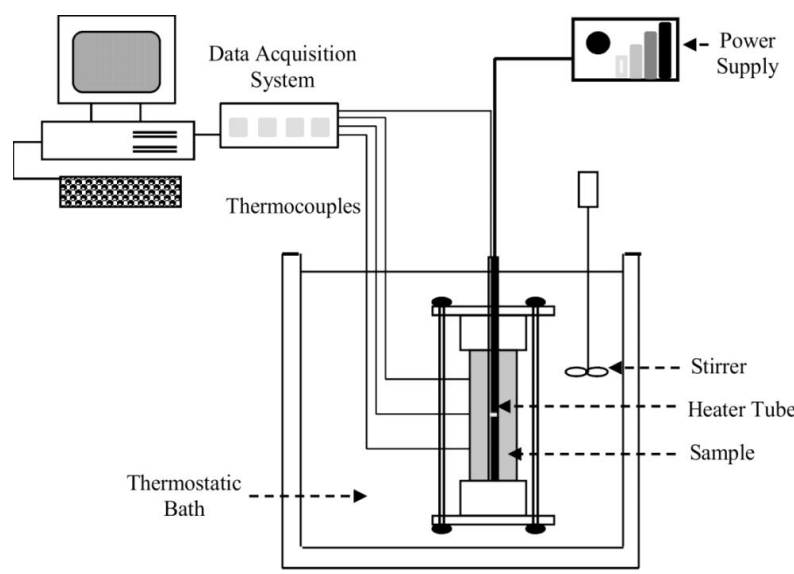

Figure 2 - Schematic diagram of the apparatus used to measure the effective thermal conductivity. power input to the heater resistance was made by means of a laboratory DC power supply (model MPS-3006D, Minipa, São Paulo, Brazil), which allowed us to adjust the current, with a stability of $0.05 \%$. The temperatures were monitored using a data logger (Model NI 9213, National Instruments, USA) and a LabVIEW data acquisition program written in $\mathrm{C}+$. To measure the temperature, four copper-constantan thermocouples were fixed on the surfaces of the inner and outer cylinders, respectively. Steady state conduction inside the cell was described by the Fourier equation in cylindrical coordinates, with the boundary conditions corresponding to the heat transfer between the two concentric cylindrical surfaces kept at constant temperatures, as described by Gabas et al. (2005).

Equation (1), as described by Bellet et al. (1975), can be used to calculate the sample thermal conductivity, $\lambda$ from the experimental measurements of $\boldsymbol{T}_{\mathbf{1}}$ and $\boldsymbol{T}_{\mathbf{2}}$ under steady state conditions.

$\lambda=q \frac{\log \left(R_{2} / R_{1}\right)}{2 \pi l\left(T_{1}-T_{2}\right)}$

where $q$ is the heat flux in the thermal resistance $(\mathrm{W}), r$ the radius (m), $R_{1}$ and $R_{2}$ respectively the external and internal radii of the cylinder $(\mathrm{m}), l=$ cell length $(\mathrm{m}), T$ the temperature $\left({ }^{\circ} \mathrm{C}\right), T_{1}$ the steady state temperature of the internal cylinder $\left({ }^{\circ} \mathrm{C}\right), T_{2}$ the steady state temperature of the thermostatic bath where the cell was immersed $\left({ }^{\circ} \mathrm{C}\right)$, and $\lambda$ the thermal conductivity of the sample at the average temperature $\left(T_{1}\right.$ $\left.+T_{2}\right) / 2\left(\mathrm{~W} \cdot \mathrm{m}^{-1} \cdot{ }^{\circ} \mathrm{C}^{-1}\right)$.

The performance of the coaxial dual-cylinder apparatus was checked for accuracy according to the procedure indicated by Telis et al. (2007), using pure water containing $0.5 \%$ agar to prevent the effect of convection during the experiments, in the range from $0^{\circ} \mathrm{C}$ to $-30^{\circ} \mathrm{C}$.

\section{RESULTS AND DISCUSSION}

Freezing point depression: Figure 3 shows the experimental freezing curves for uvaia pulp in natura and with maltodextrin.

Figure 3 shows that the freezing point depression for uvaia pulp in natura and with maltodextrin has a significant difference for each treatment, which may be due to the high soluble solids content. Table 1 shows the results obtained for the initial freezing point (IFP) for uvaia pulp in natura and for that with maltodextrin, as calculated from the respective FPD curves. 


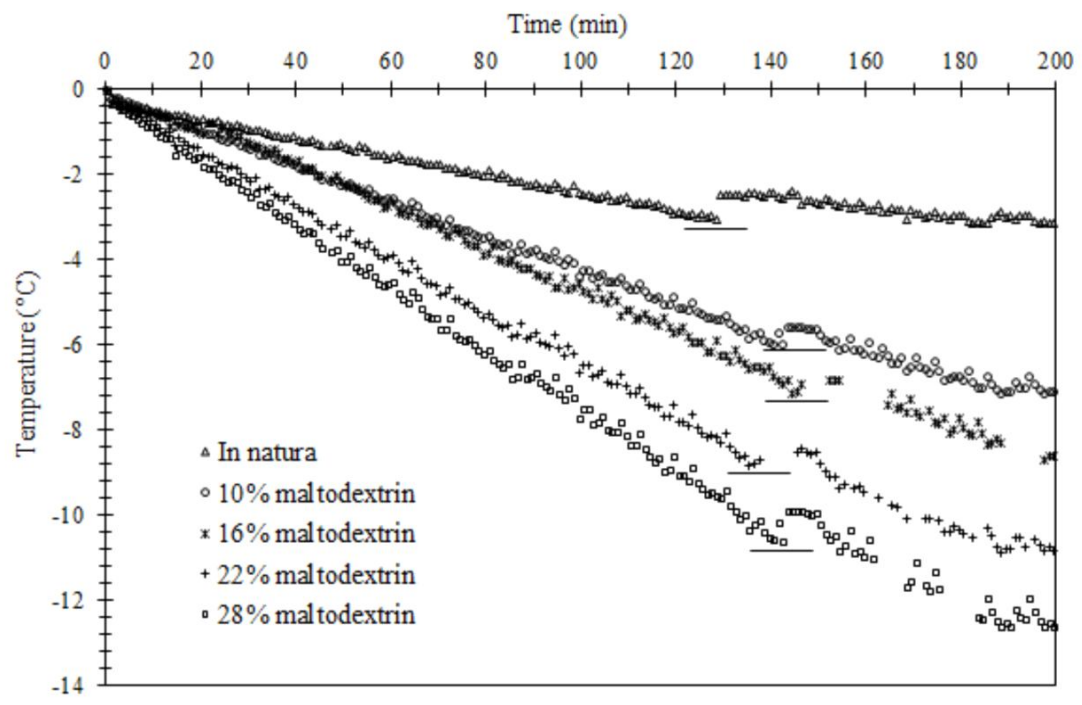

Figure 3 - Freezing point depression of uvaia pulp in natura and with 10, 16, 22, $28 \%$ maltodextrin.

Table 1 - Values for IFP*.

\begin{tabular}{lc}
\hline \multicolumn{1}{c}{ Product } & IFP $\left({ }^{\circ} \mathrm{C}\right)$ \\
\hline Uvaia pulp & $-3.10 \pm 0.02$ \\
Uvaia pulp with 10\% maltodextrin & $-6.00 \pm 0.02$ \\
Uvaia pulp with $16 \%$ maltodextrin & $-7.40 \pm 0.02$ \\
Uvaia pulp with 22\% maltodextrin & $-9.10 \pm 0.02$ \\
Uvaia pulp with 28\% maltodextrin & $-10.80 \pm 0.02$ \\
\hline
\end{tabular}

* Mean and thermocouple sensibility range.

The results obtained above are similar to those found by Auleda et al. (2011) for fruits such as apple, pear and peach. Foods consist of solid and water fractions, and as sensible heat is removed, so the temperature of the mixture containing the solids and water decreases. Just below the initial freezing point, the water begins to convert into ice. As more heat is removed, more of the water converts into ice, and the remaining solution becomes more concentrated in terms of its solids content. Due to the higher solids concentration, the temperature at which freezing will occur is depressed (GEORG-WILHELM, 1999).

As shown in Table 1, the initial freezing point was reduced with the increasing percentage of maltodextrin in uvaia pulp. This can be explained by the nature of the maltodextrin, which, like any other starch derivative, has a remarkable ability to trap and bind water molecules by means of the hydroxyl group (LOPERA et al., 2009). This interaction of water with maltodextrin is extensive, because starch is highly hygroscopic $(17.0 \leq \mathrm{DE} \geq 19.9)$. At the cellular level, the heterogeneous maltodextrin coverage is fixed to the external structure of the material, facilitating the inclusion of water from the cells and osmotic mechanisms. The molecular force of hydration increases from the outer to the inner hydration layers, which is directly related to the decrease in initial freezing point (NESVADBA, 2008). To date only simple binary systems such as waterglucose have been investigated thoroughly enough. Authors such as Mackenzie et al., (1977) suggest that the addition of emulsifying agents may affect the equilibrium melting points, heterogeneous nucleation temperatures, homogeneous nucleation temperatures, glass transition and devitrification temperatures and re-crystallisation temperatures, as well as the frozen properties of the foods. Future research should focus on these properties to provide a better understanding of the influence of concentration by emulsifying agents on the initial freezing point.

Thermal conductivity: the results of the thermal conductivity experiment on uvaia juices with maltodextrin are presented in Table 2 . Thermal conductivity was almost independent of temperature for all the juices above the freezing point. In the frozen state, however, the thermal conductivity was strongly affected by temperature, in such a way that it increased with decreasing temperature. This behavior was a consequence of the larger fraction of ice present in the samples, exposed to temperatures well below their initial freezing point. Schwartzberg (1981) presented a mathematical study of the food freezing process and reported that the thermal conductivity of ice is roughly 3.7 times larger than that of liquid water, which explains the marked increase in thermal conductivity of the foods during freezing. 
Table 2 - Thermal conductivities of uvaia juice samples with different maltodextrin contents and temperatures above freezing point.

\begin{tabular}{|c|c|c|c|c|c|c|c|c|c|c|c|c|c|c|c|}
\hline Temperature & -26 & -24 & -22 & -20 & -18 & -16 & -14 & -10 & -6 & -2 & 0 & 10 & 20 & 30 & 40 \\
\hline$\% \mathrm{MD}$ & \multicolumn{15}{|c|}{ Thermal conductivity $\left(\mathrm{W} \cdot \mathrm{m}^{-1} \cdot \mathrm{K}^{-1}\right)$} \\
\hline 0 & 1.409 & 1.396 & 1.380 & 1.383 & 1.383 & 1.353 & 1.315 & 1.193 & 0.909 & 0.485 & 0.486 & 0.492 & 0.499 & 0.507 & 0.515 \\
\hline 10 & 1.177 & 1.154 & 1.126 & 1.093 & 1.098 & 1.045 & 0.992 & 0.771 & 0.701 & 0.444 & 0.450 & 0.456 & 0.461 & 0.468 & 0.475 \\
\hline 16 & 1.014 & 0.994 & 0.979 & 0.957 & 0.911 & 0.852 & 0.777 & 0.538 & 0.425 & 0.427 & 0.428 & 0.439 & 0.444 & 0.450 & 0.456 \\
\hline 22 & 0.892 & 0.873 & 0.838 & 0.795 & 0.743 & 0.700 & 0.636 & 0.551 & 0.416 & 0.418 & 0.419 & 0.426 & 0.433 & 0.438 & 0.444 \\
\hline 28 & 0.780 & 0.808 & 0.767 & 0.717 & 0.656 & 0.581 & 0.526 & 0.389 & 0.391 & 0.394 & 0.395 & 0.401 & 0.408 & 0.414 & 0.421 \\
\hline$\% \mathrm{MD}$ & \multicolumn{15}{|c|}{ Frozen water fraction* } \\
\hline 0 & 0.747 & 0.738 & 0.729 & 0.717 & 0.702 & 0.684 & 0.660 & 0.585 & 0.410 & 0 & 0 & 0 & 0 & 0 & 0 \\
\hline 10 & 0.575 & 0.561 & 0.544 & 0.524 & 0.499 & 0.468 & 0.427 & 0.299 & 0 & 0 & 0 & 0 & 0 & 0 & 0 \\
\hline 16 & 0.499 & 0.483 & 0.463 & 0.440 & 0.411 & 0.375 & 0.329 & 0.181 & 0 & 0 & 0 & 0 & 0 & 0 & 0 \\
\hline 22 & 0.421 & 0.402 & 0.380 & 0.353 & 0.320 & 0.279 & 0.227 & 0.058 & 0 & 0 & 0 & 0 & 0 & 0 & 0 \\
\hline 28 & 0.350 & 0.329 & 0.304 & 0.275 & 0.239 & 0.194 & 0.137 & 0 & 0 & 0 & 0 & 0 & 0 & 0 & 0 \\
\hline
\end{tabular}

*Estimated using equation (2).

Table 2 shows that the thermal conductivities of uvaia pulp and of uvaia pulp with maltodextrin were not affected by a variation in temperature between 30 and 40 ${ }^{\circ} \mathrm{C}$. This thermal property of food products is mainly a function of the water content and structure. The uvaia pulp presented a slightly higher thermal conductivity compared to fruits with similar moisture content, such as papaya and mango (TELIS et al., 2007). This behavior could be attributed to the higher water content of uvaia pulp $\left(87-89 \mathrm{~kg} \cdot \mathrm{kg}^{-1}\right.$, w.b) and its smaller soluble solids content, which lead to a greater frozen water fraction at any given temperature and a consequent increase in thermal conductivity (NESVADBA, 2008). It is well known from the literature that thermal conductivity decreases with increasing food concentration (DELGADO; SUN, 2001; CHEN et al., 1996). Some authors have reported that as the sugar content increases, so the quantity of free water in the material decreases, leading to a decrease in thermal conductivity (AULEDA et al., 2011). The values obtained for the frozen water fraction presented in Table 2 were calculated using Equation 2:

$X_{i c e}=X_{w}\left(1-\frac{T_{f}}{T}\right)$

where $T$ and $T_{f}$ are, respectively, the sample temperature and the initial freezing temperature $\left({ }^{\circ} \mathrm{C}\right)$; and $X_{i c e}$ and $X_{w}$ are the mass fractions of ice (wet basis, dimensionless) and of water (dimensionless), respectively.
According to Krokida et al. (2002) and Schwartzberg (1981), experimental results for the thermal conductivity of uvaia pulp with and without maltodextrin, above and below the initial freezing point, were represented by Equations (3) and (4), respectively.

$\lambda=P_{1} T^{2}+P_{2} T+P_{3}$

$\lambda=P_{1}\left(1-\frac{P_{f}}{T}\right)+P_{2}$

where $\lambda$ is the thermal conductivity $\left(\mathrm{W} \cdot \mathrm{m}^{-1} \cdot \mathrm{K}^{-1}\right)$ and $T$ is the sample temperature $\left({ }^{\circ} \mathrm{C}\right)$. The fitting procedure was carried out by linear regression, employing the tool solver from the excel workspace. This method involved minimization of the errors between the experimental and calculted data, by adjusting and identifying the parameters for each \%MD. Tables 3 and 4 show the model parameters with their respective correlation coefficients $\left(R^{2}\right)$ and standard errors $(S E)$.

Figure 4 shows the agreement between the calculated and experimental data for the uvaia pulp with and without maltodextrin at different temperatures.

Results on the thermal conductivity and freezing point depression of uvaia pulp, are useful information to project industrial equipments and determine the molar mass of the aqueous solutions, respectively (KROKIDA et al., 2002). 
Table 3 - Estimated equation (3) parameters and statistical results.

\begin{tabular}{cccccc}
\hline$\% \mathrm{MD}$ & $P_{1}$ & $P_{2}$ & $P_{3}$ & $R^{2}$ & $S E$ \\
\hline 0 & $4.64 \times 10^{-6}$ & $6.73 \times 10^{-8}$ & 0.099 & 0.998 & $5.81 \times 10^{-4}$ \\
10 & $4.06 \times 10^{-6}$ & $6.73 \times 10^{-8}$ & 0.111 & 0.978 & $1.86 \times 10^{-3}$ \\
16 & $3.98 \times 10^{-6}$ & $6.73 \times 10^{-8}$ & 0.101 & 0.978 & $1.75 \times 10^{-3}$ \\
22 & $4.06 \times 10^{-6}$ & $6.73 \times 10^{-8}$ & 0.099 & 0.995 & $7.59 \times 10^{-4}$ \\
28 & $3.64 \times 10^{-6}$ & $6.73 \times 10^{-8}$ & 0.099 & 0.998 & $2.72 \times 10^{-4}$ \\
\hline
\end{tabular}

Table 4 - Estimated equation (4) parameters and statistical results.

\begin{tabular}{ccccc}
\hline$\% \mathrm{MD}$ & $P_{1}$ & $P_{2}$ & $R^{2}$ & $S E$ \\
\hline 0 & 1.311 & 0.275 & 0.988 & $1.91 \times 10^{-2}$ \\
10 & 0.584 & 0.700 & 0.898 & $5.80 \times 10^{-2}$ \\
16 & 1.051 & 0.281 & 0.994 & $1.36 \times 10^{-2}$ \\
22 & 0.848 & 0.339 & 0.939 & $3.16 \times 10^{-2}$ \\
28 & 0.826 & 0.337 & 0.966 & $2.16 \times 10^{-2}$ \\
\hline
\end{tabular}

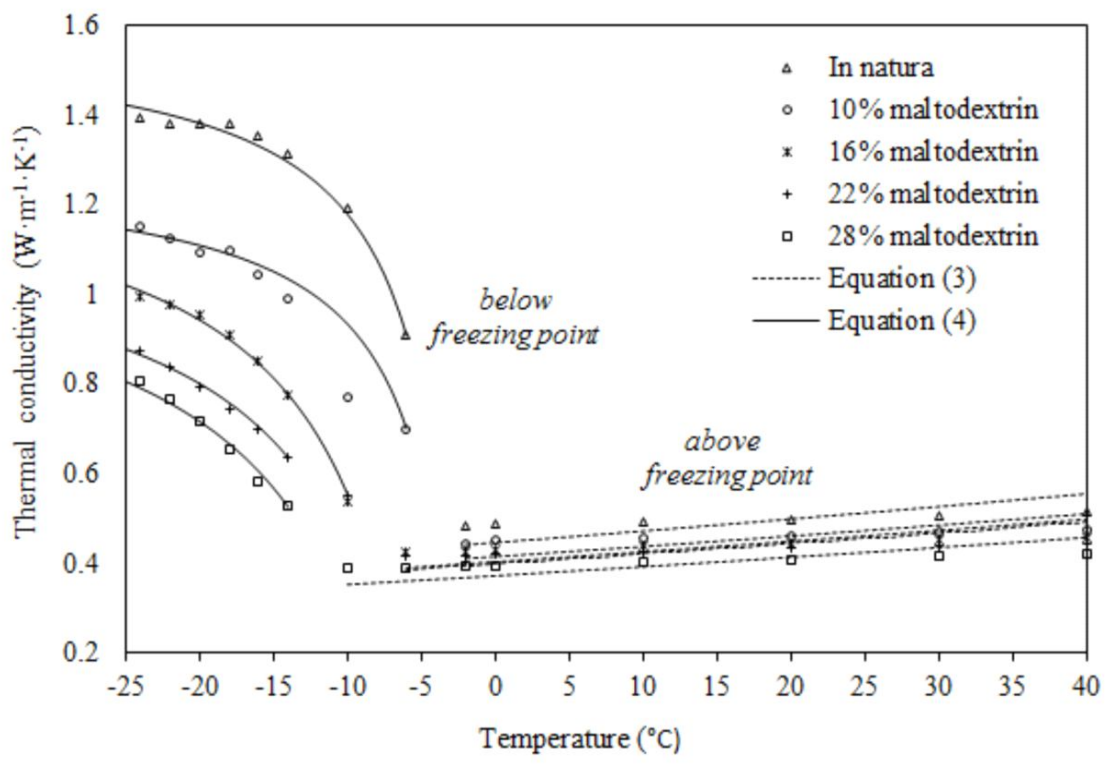

Figure 4 - Comparison between the calculated and experimental data for thermal conductivity of uvaia pulp with and without maltodextrin, at different temperatures.

\section{CONCLUSION}

The experimental values for the initial freezing point of uvaia pulp with and without maltodextrin were calculated. In the frozen state, it was observed that the thermal conductivity decreased with increasing temperature. Otherwise, the uvaia pulp alone presented a slightly higher thermal conductivity than the uvaia pulp with added maltodextrin, which could be attributed to differences in the total solids concentrations. The mass fraction of ice in both (with and without maltodextrin) pulps increased during freezing, causing an increase in thermal conductivity of the material due to the higher thermal conductivity of

Ciênc. agrotec., Lavras, v. 36, n. 1, p. 78-85, jan./fev., 2012 
ice as compared to that of liquid water. The thermal conductivities for uvaia pulp with and without maltodextrin, above and below the initial freezing point, were represented mathematically, obtaining good statistical results for each model used.

\section{ACKNOWLEDGEMENTS}

The authors are grateful to the Sao Paulo State Research Support Agency, FAPESP, for their financial support (process 2009/13033-9).

\section{REFERENCES}

ADHIKARI, B. et al. Effect of addition of maltodextrin on drying kinetics and stickiness of sugar and acid rich foods during convective drying experiments and modelling. Journal of Food Engineering, Davis, v. 62, p. 53-68, 2004.

AHMED, J. Drying of vegetables: principles and dryer desing. In: SINHA, N.K. Handbook of vegetables \& vegetable processing. Ames: Wiley-Blackwell, 2011. p. 279-297.

AULEDA, J.M. et al. Estimation of the freezing point of concentrated fruits juices for application in freeze concentration. Journal of Food Engineering, Davis, v. 105, p. 289-294, 2011.

BELLET, D.; SANGELIN, M.; THIRRIOT, C. Determination des proprietés themophysiques de liquides non-newtonies a l'áide d'une cellule a cylindres coaxiaux. International Journal of Heat and Mass Transfer, Chicago, v. 18, p. 1177-1187, 1975.

BEMILLER, J.N. Carbohydrates. In: FENEMMA, O.R. Food Chemistry. New York: Marcel Decker, 1996. p. 157224.

CHEN, P.; CHEN, X.D.; FREE, K.W. Measurement and data interpretation of the freezing point depression of milks. Journal of Food Engineering, Davis, v. 30, p. 239253, 1996.

CHOUDHARY, D.; MEHTA, A. Fruit crops. Jaipur: Oxford Book Company,2010. p. 298-303.

DELGADO, A.E.; SUN, D.W. Heat and mass transfer models for predicting freezing process - a review. Journal of Food Engineering, Davis, v. 47, p. 157-174, 2001.
DI MATTEO, P.; DONSÍ, G.; FERRARI, G. The role of heat and mass transfer phenomena in atmospheric freezing-drying of foods in a fluidized bed. Journal of Food Engineering, Davis, v. 59, p. 267-275, 2003.

DONADIO, L.C. Study of some Brazilian myrtaceae in Jaboticabal-SP. Acta Horticulturae, Leuven, v. 452, p. 181-183, 1997.

FAOSTAT, Crops production. 2009

GABAS, A.L. et al. Changes of density, thermal conductivity, themal diffusivity and specific heat of plums during drying. International Journal of Food Properties, New York, v. 8, p. 233-242, 2005.

GEORG-WILHELM, O. Freeze-Drying. Weinheim: Wiley-VCH,1999. p. 2-116.

GUEDES, R.C.M.; OLIVEIRA, W.P.; SOUZA, C.R.F. Spray drying of Eugenia pyriformis juice., 2009 p. 1-6.

JAYA, S.; DAS, H. Effect of maltodextrin, glycerol monostearate and tricalium phosphate on vacuum dried mango powder properties. Journal of Food Engineering, Davis, v. 63, p. 125-134, 2004.

KROKIDA, M.K. et al. Literature data of thermal conductivity of foodstuffs. International Journal of Food Properties, Manchester, v. 5, p. 63-111, 2002.

LERICI, C.R.; PIVA, M.; DALLAROSA, M. Water activity and freezing point depression of aqueous solutions and liquid foods. Journal of Food Science, Malden, v. 48, p. 1667-1669, 1983.

LOPERA, S.M.C. et al. Development and characterization of folic acid microparticles formed by spray-drying with gum arabic and maltodextrin. Revista Vitae, Medellín, v. 16, p. 55-65, 2009.

MACKKENZIE, A.P.; DERBYSHIRE, W.; REID, D.S.

Non-equilibrium freezing behaviour of aqueous systems, London, The Royal Society, p. 167-189.1977

NESVADBA, P. Thermal properties and ice crystal development in frozen foods. In: EVANS, J.A. Frozen food ans scient technology. Oxford: Blackwell Publishing Ltd, 2008. p. 1-26. 
REINECCIUS, GA. Carbohydrates for flavor encapsulation. Food Technology, Chicago, v. 46, p. 337-346, 1991.

RIGHETTO, A.M.; NETTO, F.M. Effect of encapsulating materials on water sorption, glass, transition and stability of juice from immature acerola. International Journal of Food Properties, Muscat, v. 8, p. 337-346, 2005.

ROUSTAPOUR, O.R.; HOSSEINALIPOUR, M.; GHOBADIAN, B. An experimental investigation of lime juice drying in a pilot plant spray dryer. Drying Techonology, Singapore, v. 24, p. 181-188, 2006.

RUFINO, M.S.M. et al. Quality for fresh consumption and processing of some non-traditional tropical fruits from Brazil. Fruits, Montpellier, v. 64, p. 361-370, 2009.

SCALON, S.P.Q.; SCALON FILHO, H.; RIGONI, M.R.

Storage and germination of Eugenia uvalha Cambess seeds. Ciência e Agrotecnologia, Lavras, v. 28, p. 12281234, 2004.

SCHWARTZBERG, H.G. Mathematical analysis of the freezing and thawing of foods. Detroit: 1981 p. 1-33.

TELIS, V.R.N. et al. Freezing point and thermal conductivity of tropical fruit pulps: mango and papaya. International Journal of Food Properties, Muscat, v. 10, p. 73-84, 2007.

TELIS-ROMERO, J. et al. Temperature and water content influence on thermophysical properties of coffe extract. International Journal of Food Properties, Muscat, v. 3, p. 375-384, 2000.

TELIS-ROMERO, J. et al. Thermophysical properties of Brazilian orange juice affected by temperature and water content. Journal of Food Engineering, Davis, v. 38, p. 27-40, 1998. 